Bangladesh J. Pl. Breed. Genet., 27(2): 25-32, 2014

\title{
GENETIC DIVERGENCE ANALYSIS IN HRDC RICE (Oryza sativa L.) HYBRIDS IN BANGLADESH
}

\author{
A. Ahmed, S. G. Shaon, M. S. Islam, P. S. Saha and M. M. Islam \\ BRAC Agricultural Research and Development Centre \\ Gazipur, Bangladesh
}

\begin{abstract}
Genetic divergence of 48 IRRI developed $F_{1}$ rice hybrids were studied through Mahalanobis $\mathrm{D}^{2}$ and principal component analysis for ten characters in Gazipur and Pabna district during dry season 2012-13. Among 48 genotypes, cluster analysis resulted in five clusters following Ward's method. During dry season for both regions, cluster I incorporated the highest number of genotypes. Significant differences among the genotypes but non-significant differences among replications were noticed for most of the parameters under study. The inter-cluster distance was larger than intra-cluster distance suggesting wider diversity among the genotypes. In Gazipur, the maximum inter-cluster $\mathrm{D}^{2}$ value was recorded between cluster III and V (6.69) and the minimum between cluster II and IV (0.69). The intra-cluster distance was maximum in cluster IV (3.60) and minimum in cluster I (0.33). In Pabna, maximum inter-cluster distance was exhibited between cluster IV and II (16.43) but minimum between cluster II and III (3.98). Maximum intra-cluster distance (4.40) was recorded in cluster IV whereas minimum in cluster I (0.83). Based on positive value of vector 1 and vector 2 , panicle number $\mathrm{m}^{-2}$, spikelet fertility $(\%)$ and 1000-grain wt. (g) had maximum contribution towards genetic divergence among the characters studied. Cluster means indicated considerable differences in the mean values of different parameters. The highest cluster means for panicle weight $(\mathrm{g})$, spikelet fertility (\%), 1000 grain wt. (g) and grain yield $\left(\mathrm{kg} \mathrm{ha}^{-1}\right)$ were derived from cluster IV. Therefore, more prominence should be given to the lines under cluster IV that having genetic potentiality to contribute better for yield maximization of hybrid rice.
\end{abstract}

Key words: Genetic divergence; $\mathrm{F}_{1}$ rice; hybrids; $\mathrm{D}^{2}$ analysis; cluster

DOI: http://dx.doi.org/10.3329/bjpbg.v27i2.27842

\section{INTRODUCTION}

World population has been increasing day by day. But population growth rate of Bangladesh is much higher than world growth rate. Demand for food is proportion to the population growth. Production of rice has to be increased by at least $60 \%$ to meet up food requirement of the increasing population by the year 2020 (Masum, 2009). National rice production increased $253 \%$ from 1960 to 2009 (14.52 to 51.33 million ton) with average annual growth rate of $2.61 \%$ in Bangladesh. Average paddy yield increased about $156 \%$ from 1960 to 2009 (1.64 to $4.19 \mathrm{t} \mathrm{ha}^{-1}$ ) with $1.93 \%$ average annual compound growth (Harun et al., 2011). The possibility of expanding the area under rice in near future is limited. Moreover the arable land is decreasing at the rate of $1 \%$ per annum (BBS, 2011). Efforts aimed at breaking the yield barrier in rice have been amply demonstrated by Luo (2010), Kim and Kim (2009) and Tiwari et al. (2011). Hybrid rice 
has 20-30\% yield advantage over inbred varieties (Julfiquar, 2009). Peng et al. (2003) mentioned that the average yield of $\mathrm{F}_{1}$ hybrid rice was $4 \%$ higher than that of indica inbred in the 1999 dry season. Among different eco-systems, production of rice in Bangladesh is the most convenient to irrigated boro. In Bangladesh, hybrid rice gains positive response in boro season (Haque and Biswas, 2011). Area under boro season is the second highest which is about $39.80 \%$ of total rice land and contributes $52.07 \%$ of the total rice production (Anonymous, 2012).

In Bangladesh, research and development of hybrid rice technology was initiated in 1993 with the introduction of rice hybrids and parent materials from International Rice Research Institute (IRRI). Very limited work on the aspect of genetic diversity in hybrid rice is available on literature. However, comprehensive analysis of genetic diversity in numerous field crops and maximum exploitation of the genetic resources have been reported by many researchers (Belaj et al., 2002). Hybrid Rice Research and Development Consortium (HRDC) was formed in 2008 at International Rice Research Institute (IRRI) with the aim of accelerating the adoption of the technology.

The present study was, therefore, focused on identification of promising hybrids among 48 IRRI developed hybrid rice lines based on its performance in contribution to genetic divergence under two different agro-ecological zones of Bangladesh and an attempt was made to classify and understand the nature and magnitude of genetic diversity.

\section{MATERIALS AND METHODS}

An on farm trial was established with $48 \mathrm{~F}_{1}$ rice hybrids from IRRI with two popular BRAC hybrids Aloran, Shakti and a popular modern inbred variety BRRI dhan28 during dry season 2012 in BRAC Agricultural Research and Development Centre (BARDC), Gazipur and Dashuria Seed Farm, Pabna. The experiment was conducted in Randomized complete block design with three replications. Each plot measures 4.0 meter long and 2.0 meter wide in BARDC and 3.8 meter long and 2.2 meter wide in Dashuria Seed Farm. Thirty to forty days old seedlings of each genotype were transplanted at a spacing of 20 $\mathrm{cm} \times 20 \mathrm{~cm}$ with single seedling hill ${ }^{-1}$. Gap filling was done a week after transplanting. Urea, TSP, MoP, Gypsum and $\mathrm{ZnSO}_{4}$ fertilizer were applied at the rate of 270-130-120$70-10 \mathrm{~kg} \mathrm{ha}^{-1}$ as standard practice based on SRDI recommendation during dry season. The whole amount of TSP, Gypsum, two third of MoP and one fourth of urea were mixed properly and applied as basal application. $\mathrm{ZnSO}_{4}$ was applied separately to avoid fixation with Phosphorus. The remaining urea was applied in three equal splits at 15 DAT, maximum tillering stage and just before panicle initiation. The rest amount of MoP was applied before panicle initiation stage. Weeding was done two to three times and insecticides were applied as and when necessary to keep the fields free from insectpests. All other cultural package and practices were maintained to raise a good and healthy crop.

Three hills (excluding border hills) from each plot were selected and tagged after transplanting for taking yield and yield components data at harvest stage. The observations were recorded on plant height $(\mathrm{cm})$, panicles number $\mathrm{m}^{-2}$, days to $50 \%$ flowering; growth duration (days), panicle length $(\mathrm{cm})$, spikelet panicle ${ }^{-1}$, panicle weight $(\mathrm{g})$, spikelet fertility $(\%), 1000$ grain weight $(\mathrm{g})$ and grain yield $\left(\mathrm{kg} \mathrm{ha}^{-1}\right)$. The grain yield was adjusted to $14 \%$ moisture content and converted to kilogram per hectare. The genetic distance between the genotypes was worked out using PCA and Mahalanobis (1936) $\mathrm{D}^{2}$ analysis expanded by Euclidean and grouping of genotypes into clusters was accomplished following the Ward's method (1963).The statistical analysis was carried out using computer software STAR version 2.0.1 (2014). 


\section{RESULTS AND DISCUSSION}

Significant differences among the genotypes but non-significant differences among replications were showed for most of the parameters under study (Table 1). On the basis of degree of divergence, by the application of non-hierarchical clustering using covariance matrix, the 48 genotypes tested for dry season in Gazipur and Pabna were grouped into five clusters (Table 2) and (Table 6).

In the dry season at Gazipur, distribution pattern indicated the highest numbers of genotypes (20) were aggregated in cluster I and cluster IV has the minimum number of entries (4), while cluster II, III and V comprised 9, 8 and 7 genotypes, respectively. Huidong and Shiliang (1987) have reported that based on hierarchical and dynamic clustering, the recurrence of the entries in a given cluster is escalated with the increasing of number of parameters under study.

Table 1. Mean squares for ten characters of HRDC genotypes during dry season in Gazipur and Pabna

\begin{tabular}{|c|c|c|c|c|c|c|}
\hline \multirow{3}{*}{ Characters } & \multicolumn{6}{|c|}{ Source of variance M.S (df) } \\
\hline & \multicolumn{2}{|c|}{ Replications (2) } & \multicolumn{2}{|c|}{ Genotypes (47) } & \multicolumn{2}{|c|}{ Error (94) } \\
\hline & Gazipur & Pabna & Gazipur & Pabna & Gazipur & Pabna \\
\hline Plant height $(\mathrm{cm})$ & $20.2^{\mathrm{ns}}$ & $70.0^{*}$ & $221.2^{* *}$ & $137.9 * *$ & 10.21 & 14.64 \\
\hline Panicle number $\mathrm{m}^{-2}$ & $1164.5^{\mathrm{ns}}$ & $958.18^{\mathrm{ns}}$ & $3080.3 * *$ & $2818.9 * *$ & 703.1 & 1193.01 \\
\hline Days to $50 \%$ flowering & $0.583^{\mathrm{ns}}$ & $0.298^{\mathrm{ns}}$ & $59.32 * *$ & $67.96 * *$ & 0.484 & 2.24 \\
\hline Growth duration (days) & $10.64 * *$ & $3.96 * *$ & $173.1 * *$ & $54.09 * *$ & 1.43 & 0.241 \\
\hline Panicle length $(\mathrm{cm})$ & $1.82^{\mathrm{ns}}$ & $3.1 *$ & $5.46^{* *}$ & $6.05 * *$ & 0.87 & 0.948 \\
\hline Panicle weight (g) & $0.181^{\mathrm{ns}}$ & $0.746^{*}$ & $0.58 * *$ & $0.611 * *$ & 0.07 & 0.218 \\
\hline Spikelet panicle ${ }^{-1}$ & $28.78 * *$ & $920.56^{\mathrm{ns}}$ & $3767.2 * *$ & $3014.9 * *$ & 416.1 & 890.6 \\
\hline Fertility $\%$ & $56.3^{\mathrm{ns}}$ & $11.19^{\mathrm{ns}}$ & $107.3^{* *}$ & $133.61 * *$ & 25.16 & 43.52 \\
\hline 1000-grain wt. (g) & $0.495^{\mathrm{ns}}$ & $17.21 * *$ & $21.26 * *$ & $20.8^{* *}$ & 0.463 & 0.895 \\
\hline Yield $\left(\mathrm{kg} \mathrm{ha}^{-1}\right)$ & $939639.8 * *$ & $788205.14 *$ & $1277639.2 * *$ & $2212027.3^{* *}$ & 158333.7 & 245668.3 \\
\hline
\end{tabular}

ns=Non-significant; *=Significant; **=Highly significant; $\mathrm{df}=$ Degree of freedom

Table 2. Grouping of 48 HRDC rice hybrids into five clusters by Ward's method grown during dry season in Gazipur

\begin{tabular}{|c|c|c|c|}
\hline Cluster & $\begin{array}{l}\text { Sl No. of the } \\
\text { genotypes }\end{array}$ & $\begin{array}{c}\text { No. of } \\
\text { genotypes }\end{array}$ & Name of genotypes \\
\hline I & $\begin{array}{l}1,7,8,9,11 \\
13,14,18,20 \\
23,24,25,26 \\
27,28,29,30 \\
33,37,45\end{array}$ & 20 & $\begin{array}{l}\text { HRDC 1301, HRDC 1308, HRDC 1309, HRDC 1310, HRDC } \\
\text { 1312, HRDC 1314, HRDC 1315, HRDC 1319, } \\
\text { HRDC 1325, HRDC 1328, HRDC 1329, HRDC 1330, HRDC } \\
\text { 1331, HRDC 1332, HRDC 1333, HRDC 1334, HRDC 1335, } \\
\text { HRDC 1338, HRDC 1342, HRDC } 1350\end{array}$ \\
\hline II & $\begin{array}{l}2,3,4,17,38 \\
39,40,41,42\end{array}$ & 9 & $\begin{array}{l}\text { HRDC 1303, HRDC 1304, HRDC 1305, HRDC 1318, HRDC } \\
1343, \text { HRDC } 1344, \text { HRDC } 1345, \text { HRDC } 1346, \text { HRDC } 1347\end{array}$ \\
\hline III & $\begin{array}{l}5,6,10,15 \\
19,21,22,31\end{array}$ & 8 & $\begin{array}{l}\text { HRDC 1306, HRDC 1307, HRDC 1311, HRDC 1316, HRDC } \\
\text { 1324, HRDC 1326, HRDC 1327, HRDC } 1336\end{array}$ \\
\hline IV & $12,35,36,46$ & 4 & HRDC 1313, HRDC 1340, HRDC 1341, Aloran \\
\hline V & $\begin{array}{l}16,32,34,43 \\
44,47,48\end{array}$ & 7 & $\begin{array}{l}\text { HRDC 1316, HRDC 1337, HRDC 1339, HRDC 1348, HRDC } \\
\text { 1349, BRRI dhan28, Shakti }\end{array}$ \\
\hline
\end{tabular}

All the inter-cluster distances were larger than the intra-cluster distances indicating presence of wider diversity among genotypes of distance groups (Table 3) \& (Table 7). The result was in conformity with the findings of Nayak et al. (2004). The largest intra- 
cluster distance was recorded for cluster IV (3.60) express that the entries included in this cluster was relatively more diverse than those in the other clusters and the lowest in cluster I (0.33) which indicated homogeneous nature of the genotypes within the clusters. The maximum inter-cluster distances were noted between cluster III and V (6.69) pursued by cluster II and V (6.07), cluster I and V (5.52), cluster IV and IV (5.44), and the minimum between cluster II and IV (0.69).

Table 3. Average Intra (bold) and inter-cluster $\mathrm{D}^{2}$ values among five clusters of $48 \mathrm{HRDC}$ rice hybrids grown during dry season in Gazipur

\begin{tabular}{c|c|c|c|c|c}
\hline Cluster & I & II & III & IV & V \\
\hline I & $\mathbf{0 . 3 3}$ & & & \\
II & 3.76 & $\mathbf{1 . 8 4}$ & & & \\
III & 2.42 & 2.00 & $\mathbf{1 . 4 9}$ & & \\
IV & 3.89 & 0.69 & 2.51 & $\mathbf{3 . 6 0}$ & \\
V & 5.52 & 6.07 & 6.69 & 5.44 & $\mathbf{0 . 4 3}$ \\
\hline
\end{tabular}

Table 4. Cluster means for ten characters of HRDC genotypes during dry season in Gazipur

\begin{tabular}{l|c|c|c|c|c}
\hline \multirow{2}{*}{ Traits } & \multicolumn{5}{c}{ Cluster means } \\
\cline { 2 - 6 } & I & II & III & IV & V \\
\hline Plant height (cm) & 110.2 & 109 & 118.6 & 111.9 & 102.2 \\
Panicle number m-2 & 254.4 & 270.7 & 218.7 & 206.1 & 226.9 \\
Days to 50\% flowering & 123.6 & 119.4 & 123.6 & 122 & 113.4 \\
Growth duration (days) & 152.8 & 143.7 & 150.7 & 152.8 & 135.4 \\
panicle length (cm) & 24.2 & 25.9 & 26.0 & 25.4 & 23.7 \\
Panicle weight (g) & 2.2 & 2.2 & 2.6 & 3.3 & 2.5 \\
Spikelet panicle & 188.1 & 163.4 & 213.6 & 181.7 & 201.9 \\
Fertility (\%) & 53.1 & 59.5 & 56.1 & 67.5 & 54.1 \\
1000-grain wt. (g) & 23.1 & 22.8 & 22.9 & 27.7 & 24.4 \\
Yield (kg ha $^{-1}$ ) & 7004 & 7021 & 7228 & 8002 & 6037 \\
\hline
\end{tabular}

Cluster mean values of ten different parameters are exhibited in Table 4. Mean performance of different clusters for the characters revealed that maximum good characters i.e. the highest spikelet fertility (\%), panicle weight and 1000 grain weight $(\mathrm{g})$ were accumulated in cluster IV and as a result higher grain yield $\left(8002 \mathrm{~kg} \mathrm{ha}^{-1}\right)$ was obtained in this cluster. Moreover, the highest plant height $(\mathrm{cm})$, days to $50 \%$ flowering, panicle length $(\mathrm{cm})$ and spikelet panicle ${ }^{-1}$ bearing genotypes were clubbed into cluster III whereas cluster I and $\mathrm{V}$ possessed low yielding genotypes with low fertility percentage, panicle length $(\mathrm{cm})$ and panicle weight $(\mathrm{g})$.

Results of relative contributions of the characters towards divergence are portrayed in Table 5. In Gazipur site, the canonical vector analysis revealed that the vectors (vector 1 and 2) for only panicle number $\mathrm{m}^{-2}$ were positive. Such results indicated that this single character contributed maximum towards divergence. In Pabna site, vector 1 obtained from PCA explained that plant height and all yield contributing characters except panicle number $\mathrm{m}^{-2}$ contributed towards genetic divergence among the genotypes; whereas in vector 2 , panicle number $\mathrm{m}^{-2}$, spikelet fertility $(\%)$ and 1000 -grain wt. (g) played their role in genetic divergence . Choudhury et al. (1999) also mentioned that plant height contributes the highest for genetic divergence. Both the vectors had positive values for spikelet fertility (\%) and 1000-grain wt. (g) indicated the highest contributions of these traits towards the divergence among $48 \mathrm{~F}_{1}$ rice hybrids. 
Table 5. Latent vectors for ten principle traits of 48 HRDC rice hybrids during dry season in Gazipur and Pabna

\begin{tabular}{l|c|c|c|c}
\hline \multirow{2}{*}{ Traits } & \multicolumn{2}{c|}{ Vector 1 } & \multicolumn{2}{c}{ Vector 2 } \\
\cline { 2 - 5 } & Gazipur & Pabna & Gazipur & Pabna \\
\hline Plant height (cm) & -0.183 & 0.166 & -0.202 & -0.248 \\
Panicle no. m m $_{\text {Days to 50\% flowering }}$ & 0.375 & -0.468 & 0.312 & 0.014 \\
Growth duration (days) & -0.082 & 0.012 & -0.519 & -0.454 \\
Panicle length (cm) & -0.123 & 0.056 & -0.504 & -0.205 \\
Panicle weight (g) & -0.151 & 0.219 & -0.063 & -0.254 \\
Spikelet panicle & -0.461 & 0.478 & 0.103 & -0.021 \\
Fertility (\%) & -0.169 & 0.234 & 0.3 & -0.407 \\
1000-grain wt (g) & -0.357 & 0.282 & -0.075 & 0.406 \\
Yield (kg ha $^{-1}$ ) & -0.117 & 0.127 & -0.056 & 0.271 \\
\hline
\end{tabular}

Table 6. Grouping of 48 HRDC rice hybrids into five clusters by Ward's method grown during dry season in Pabna

\begin{tabular}{|c|c|c|c|}
\hline Cluster & $\begin{array}{l}\text { Sl No. of the } \\
\text { genotypes }\end{array}$ & $\begin{array}{c}\text { No. of } \\
\text { genotypes }\end{array}$ & Name of genotypes \\
\hline I & $\begin{array}{l}1,2,3,4,8,9,11, \\
14,17,18,24,29, \\
37,38,45\end{array}$ & 15 & $\begin{array}{l}\text { HRDC } 1301, \text { HRDC } 1303, \text { HRDC } 1304, \text { HRDC } 1305 \text {, } \\
\text { HRDC } 1309, \text { HRDC } 1310, \text { HRDC } 1312, \text { HRDC } 1315 \text {, } \\
\text { HRDC } 1318, \text { HRDC } 1319, \text { HRDC } 1329, \text { HRDC } 1334, \\
\text { HRDC } 1342, \text { HRDC } 1333 \text {, HRDC } 1348\end{array}$ \\
\hline II & $\begin{array}{l}5,7,16,20,22 \\
23,30,33,34,39 \\
40,42,43,44\end{array}$ & 14 & $\begin{array}{l}\text { HRDC } 1306, \text { HRDC } 1308, \text { HRDC } 1317, \text { HRDC } 1325 \text {, } \\
\text { HRDC } 1327, \text { HRDC } 1328, \text { HRDC } 1335 \text {, HRDC } 1338 \text {, } \\
\text { HRDC } 1339 \text {, HRDC } 1344, \text { HRDC } 1345 \text {, HRDC } 1347 \text {, } \\
\text { HRDC } 1348, \text { HRDC } 1349\end{array}$ \\
\hline III & $\begin{array}{l}6,10,13,15,19 \\
21,25,26,27 \\
28,31\end{array}$ & 11 & $\begin{array}{l}\text { HRDC 1307, HRDC 1311, HRDC 1314, HRDC 1316, } \\
\text { HRDC 1324, HRDC 1326, HRDC 1330, HRDC 1331, } \\
\text { HRDC 1332, HRDC1333, HRDC } 1336\end{array}$ \\
\hline IV & $12,35,36,41,46$ & 5 & $\begin{array}{l}\text { HRDC 1313, HRDC 1340, HRDC 1341, HRDC 1346, } \\
\text { Aloran }\end{array}$ \\
\hline $\mathrm{V}$ & $32,47,48$ & 3 & HRDC 1337, BRRI dhan28, Shakti \\
\hline
\end{tabular}

In Pabna site, cluster I contained the highest number of genotypes (15) followed by cluster II constituted by 14 genotypes. Cluster V consisted of minimal number of genotypes (3). Cluster III and IV incorporated 11 and 5 genotypes, respectively.

The inter and intra-cluster distances range from 3.98 to 16.43 and 0.83 to 4.40 , respectively, which clearly indicated the existence of variability in the germplasm of dissimilar clusters. Regarding inter-cluster distance, cluster IV appeared maximum genetic distance (16.43) from cluster II pursued by cluster III (13.37) from cluster IV and cluster I (11.91) from cluster IV. The minimum inter-cluster distance was observed between cluster II and III (3.98) and cluster I and III (4.45) revealing that the genotypes of these clusters were genetically similar. The intra-cluster degree of diversity was maximum in cluster IV (4.40) and minimum in cluster I (0.83), indicating that the genotypes in cluster IV were more heterogeneous and those in cluster I were homogeneous in nature. Previously, Iftekharuddaula et al. (2002) examined divergence in Boro rice and reported the homogeneous nature of the genotypes within the clusters. Cluster means illustrated considerable differences in the mean values of different parameters. The maximum average values for panicle number $\mathrm{m}^{-2}$, panicle length $(\mathrm{cm})$, panicle weight $(\mathrm{g})$, spikelet fertility $(\%)$ and 1000 grain wt. (g) were noted in cluster IV indicated that the lines clubbed in this cluster had the genetic capability to provide better 
for yield escalation of hybrid rice. Highest plant height along with maximum days to $50 \%$ flowering and spikelet panicle ${ }^{-1}$ bearing genotypes were gathered into cluster III. The lowest mean values for plant height $(\mathrm{cm})$, days to 50\% flowering, growth duration (days), panicle length $(\mathrm{cm})$, spikelet panicle ${ }^{-1}$ and grain yield $\left(\mathrm{kg} \mathrm{ha}^{-1}\right)$ were observed in cluster V.

Table 7. Average Intra (bold) and inter-cluster $\mathrm{D}^{2}$ values among five clusters of $48 \mathrm{HRDC}$ rice hybrids grown during dry season in Pabna

\begin{tabular}{c|c|c|c|c|c}
\hline Cluster & I & II & III & IV & V \\
\hline I & $\mathbf{0 . 8 3}$ & & & & \\
II & 5.05 & $\mathbf{1 . 9 7}$ & & & \\
III & 4.45 & 3.98 & $\mathbf{1 . 4 7}$ & & \\
IV & 11.91 & 16.43 & 13.37 & $\mathbf{4 . 4 0}$ & \\
V & 8.98 & 10.60 & 6.61 & 9.91 & $\mathbf{0 . 8 9}$ \\
\hline
\end{tabular}

Table 8. Cluster means for ten characters of HRDC genotypes during dry season in Pabna

\begin{tabular}{|c|c|c|c|c|c|}
\hline \multirow{2}{*}{ Traits } & \multicolumn{5}{|c|}{ Cluster means } \\
\hline & $\mathbf{I}$ & II & III & IV & $\mathbf{V}$ \\
\hline Plant height (cm) & 95.3 & 95.4 & 102.8 & 94.3 & 93.3 \\
\hline Panicle number $\mathrm{m}^{-2}$ & 267.1 & 225.1 & 219.9 & 208.2 & 239.8 \\
\hline Days to $50 \%$ flowering & 131 & 129 & 131 & 130 & 116 \\
\hline Growth duration (days) & 152 & 153 & 152 & 154 & 144 \\
\hline panicle length $(\mathrm{cm})$ & 24.5 & 24.8 & 25.2 & 25.8 & 22.3 \\
\hline Panicle weight (g) & 2.1 & 2.3 & 2.7 & 3.1 & 2.6 \\
\hline Spikelet panicle ${ }^{-1}$ & 151 & 149 & 209 & 156 & 127 \\
\hline Fertility (\%) & 63.9 & 68.1 & 65.8 & 79.2 & 69.4 \\
\hline 1000-grain wt. (g) & 22.3 & 23.7 & 20.6 & 25.7 & 24.7 \\
\hline Yield $\left(\mathrm{kg} \mathrm{ha}^{-1}\right)$ & 5983 & 6069 & 6071 & 6719 & 3567 \\
\hline
\end{tabular}

Mean sum of squares for all the characters were highly significant due to genotypes indicating wide range of variability among the genotypes for these traits in both locations. In Gazipur and Pabna sites, the genotypes under cluster IV gave the highest yield because of attain higher panicle weight, spikelet fertility (\%) and 1000grain wt. than other clusters. The higher grain yield was gained in Gazipur compare to Pabna site in case of all the clusters but the highest $\left(8002 \mathrm{~kg} \mathrm{ha}^{-1}\right)$ among all the clusters between two sites was obtained from cluster IV in Gazipur site because of produce highest mean of panicle weight $(3.3 \mathrm{~g})$ and 1000 -grain wt. $(27.7 \mathrm{~g})$. The common best performing $F_{1}$ rice hybrids in both the studied sites was HRDC 1313, HRDC 1340, HRDC 1341 and Aloran.

In addition to general features of variation and divergence indicated, this study provides the information on the potent characters that contributes to the divergence between the genotypes. The sort of genetic diversity derived among the genotypes belonging to different agro-climatic zones might be due to difference in adaptation and 
environmental conditions (Nayak et al., 2004). This study, which used multivariate techniques to assess the extent of genetic variation in 48 IRRI developed $F_{1}$ rice hybrids, was a first step in gaining an insight into the germplasm divergence, which is an important step towards an efficient exploitation of genetic resources of HRDC genotypes. Finally it can be concluded that the genotypes under cluster IV should be selected to increase total production during dry season in Bangladesh.

\section{REFERENCES}

Anonymous. 2012. Target and achievements of crop production in 2011-12. Department of Agriculture Extension, Ministry of Agriculture, Khamarbari, Farmgate, Dhaka, Bangladesh.

BBS. (Bangladesh Bureau of Statistics) 2011. Statistical Year Book of Bangladesh 2011. Bangladesh Bureau of Statistics Division, Ministry of Planning, Govt. of the people's Republic of Bangladesh, Dhaka.

Belaj, A., Z. Satovic, L. Rallo and I. Trujillo. 2002. Genetic diversity and relationship in olive (Oleaeuropea L) germplasm collection as determined by RAPD. Theor. Appl. Genet., 105: 638-644.

Choudhury, D. A., A. Hamid, A. Bhowmik, G. U. Mian and M. S. Islam. 1999. Genetic divergence in indigenous rice (Oryza sativa L) varieties of Bangladesh. Bangladesh J. Pl. Breed. Genet. 12(1 \& 2):33-36.

Harun, A. R., A. W. Julfiquar and S. Ali. 2011. A study on hybrid rice in Bangladesh: History, impact and current status of hybrid rice research, development and delivery in Bangladesh. Proc. Int. Food Policy Res. Inst.

Haque, M. M. and J. K. Biswas. 2011. Annual Research Review. Plant Physiology Division. Bangladesh Rice Research Institute, Joydebpur, Gazipur, Bangladesh.

Huidong, M. and G. Shiliang. 1987. Cluster analysis for agronomic characters of barley varieties in Jiangsuzhejiang Shanghais area. Sci. Agric. Sinica. DOI: CNKI: SUN: ZNYK.0.1987-03-004.

Iftekharuddaula, K. M., K. Akter, M. K. Bashar and M. R. Islam. 2002. Genetic parameters and cluster analysis of panicle traits in irrigated rice. Bang. J. Pl. Breed. Genet., 15: 49-55.

Julfiquar, A. W., S. S. Virmani, M. M. Haque, M. A. Mazid, and M. M. Kamal. 2009. Hybrid rice in Bangladesh: opportunities and challenges. Rice research for food security and poverty allevation. Proc. Int. Rice Research Conference.

Kim, Y. S. and J. K. Kim. 2009. Rice transcription factor AP37 involved in grain yield increase under drought stress. Plant Signal Behav. 4:735-736.

Luo, L. J. 2010. Breeding for water-saving and drought-resistant rice (WDR) in China. J. Exp. Bot. 61:3509-3517.

Mahalanobis, P. C. 1936. On the Generalized distance in statistics. Proc. Natl, Inst. Sci., India, 2: 49-55.

Masum, M. 2009. Impact of hybrid rice on Bangladesh. In: "The Guardian" pp. 56-58. Reg. No. DA816. Vol. XIX. Issue 3. 3 May 2009. Bangladesh. (email: guardian@btcl.net.bd).

Nayak, A. R., D. Chaudhary and J. N. Reddy. 2004. Genetic divergence in scented rice. Oryza 41(3-4): 79-82.

Peng,, S., J. Yang, R. C. Laza, A. L. Sanico, R. M. Visperas and T. T. Song. 2003. Physiological bases of heterosis and crop management strategies for hybrid rice in the tropics. In: Virmani, S. S., C. X. Mao and B. Dardy (eds.) Hybrid Rice for Food Security, Poverty Alleviation, and Environment Protection. Proc. 4th Intl. 
Symp.Hybrid Rice, 14-17 May 2002, Hanoi, Vietnam. Los Baños (Philippines): Intl. Rice Res. Inst. pp. 153-170.

Tiwari, D. K., P. Pandey, S. P. Giri and J. L. Dwivedi. 2011. Heterosis studies for yield and its components in rice hybrids using CMS system. Asian J. Plant Sci., 10:2942.

Ward, J. H., Jr. 1963. Hierarchical Grouping to Optimize an Objective Function, Journal of the American Statistical Association, 58, 236-244. 